Historic, Archive Document

Do not assume content reflects current scientific knowledge, policies, or practices. 



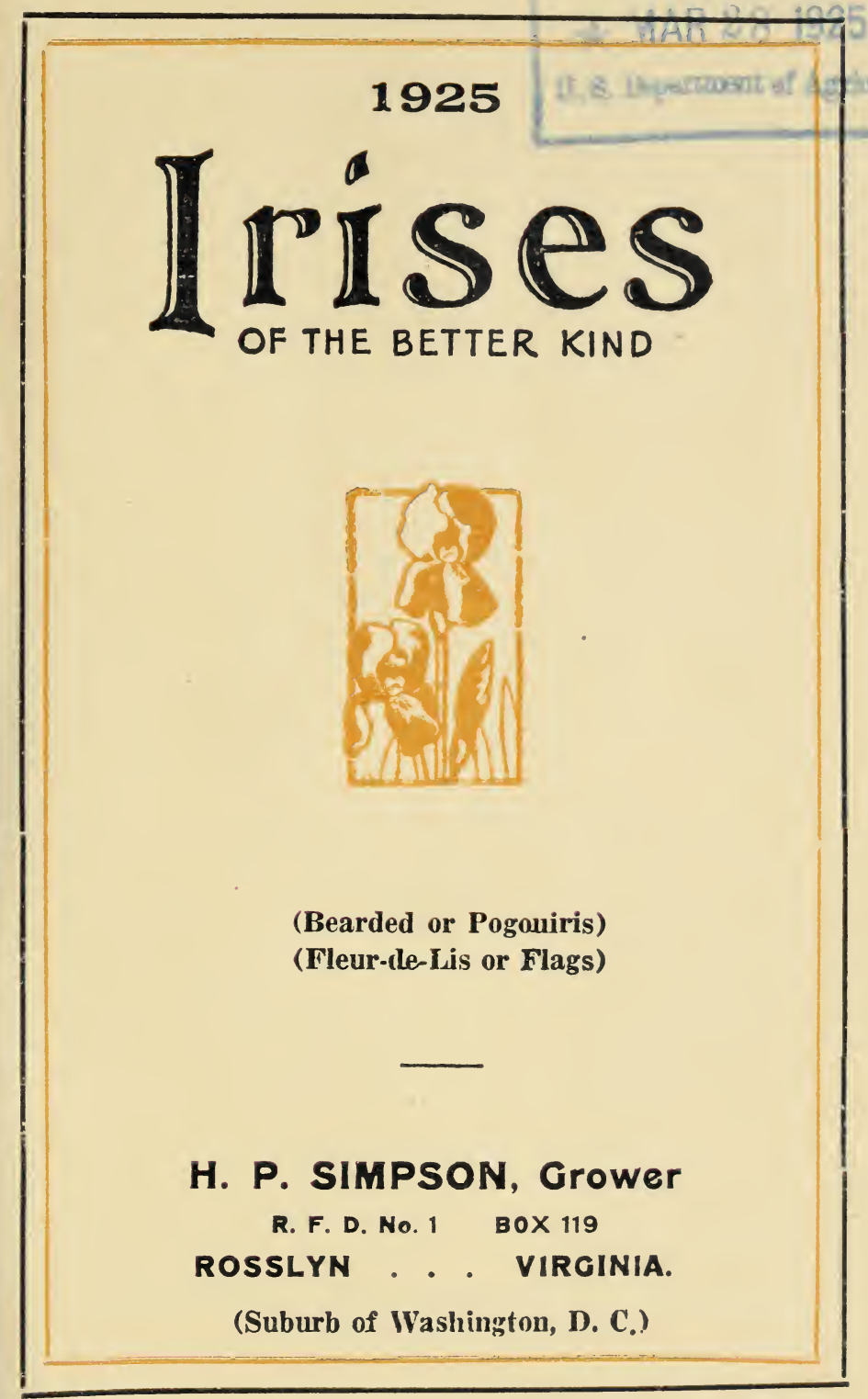


"We continued the pilgrimage, passing up Pennsylvania Avenue, through antiquated Georgetown,over the new marble Key Bridge into 'Dixie Land,' where H.P. Simpson grows his Iris. Mr. Farr had said at the lunch that he had seen so many blooms at the show and in the gardens that he was Iris-drunk; before he got away from Mr. Simpson's he must have surely had a 'jag' on. Squalens, plicatas, variegatas, and all of the other types were magnificently represented in his new seedlings, many of which he did not exhibit at the show. The Virginia mud stuck close but the memory of these glorious blooms that we saw, of the lessons we learned, and of the friendships we made, will stick even closer."J. M. R. Adams in the 


\section{CLASSIFICATION OF VARIETIES}

Varieties are listed and classified according to their main color scheme, and though this is difficult at times, it is believed to be much better than the old and now confusing classification into neglecta, amoena, variegata, etc., groups which nowadays tell you nothing in many cases, of the dominating color of the variety. "S" means "Standards," or upright petals; "F" means "Falls," or the drooping petals.

For your convenience however, if you have become accustomed to the old classification, it is briefly given and explained below:

Amoena ("pleasing") - the standards are mostly white with the falls usually of a blue or violet shade.

Germanica-of early flowering habits and shades of blue to purple with falls of darker shades.

Neglecta ("neglected")-standards range from lavender to purple with falls of darker shades.

Pallida ("pallid") - light and dark shades of blue, lavender and purple with numerous approaches to pink and red; generally tall or fairly tall growth.

Plicata ("pleated")-Standards and falls usually have a colored frill-like margin on a white ground.

Squalens ("daubed")-standards of clouded shades of fawn, copper or bronze, with darker falls of purple or browncrimson shades.

Variegata ("variegated")—standards of various shades of yellow, with brownish falls.

\section{NAMES OF INTRODUCERS}

The American introducers or hybridists named after the varieties are Farr, Morrison, Miss Sturtevant, Kennicott, Williamson and Fryer; the English are Foster, Yeld, Ware, Parker, Barr and Perry; the French are Lemon, Cayeux, Jacques, Verdier and Vilmorin; the German are Goos \& Koeneman (G. \& K.). 


\section{$=$ \\ THE VARIETIES \\ White or White Effects}

ALBICANS-The old-fashioned early white. A large bloom of fine shape. Fragrant. Shy bloomer, however, and more than one root should be planted if you wish a bloom or blooms the first season. This is believed to be an Arabian plant, but there is still some uncertainty as to its origin.

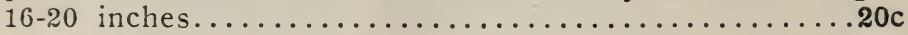

ANNA FARR (Farr, 1913)-S. delicately feathered with pale blue; F. pure white with a touch of blue at the base. A white effect from a distance. An uncertain grower in some localities, but a beautiful bloom. One of the finest in its class. 36 inches...................\$1.00

FAIRY (Kennicott, 1905)-White, delicately bordered and suffused pale blue. A very pretty bloom. Stems 36 inches tall and slightly bending, which is its only fault; not new and not as well known as it deserves to be......25c

"Its standards and falls resemble sunkissed snow outlined by the faint azure of the sky."

FENELLA (Morrison, 1921)-A good, pure sturdy white of vigorous growth on 18-24 inch stems; "not tall, but so floriferous, the flowers so well carried and proportioned that I think it will prove the most effective white for garden massing," says Mr. Sturtevant, Secretary of the A. I. S. Arched standards and flaring falls.............75c

"A fine white that I would rate 85 or over," says one authority.

INNOCENZA (Lemon, about 1854)-S. and F. ivorywhite with a crest of rich gold. Not large, but a good grower and a delicate, charming iris. Said by one authority that "in masses it seems to be our greatest white variety. One of our latest bloomers, 26 inches...........25c

KASHMIR WHITE (Foster, 1913) - A most beautiful white hybrid that we owe to Sir Michael Foster. Flowers of stout texture and perfect shape on 36-40 inch stems. The finest white within reach of the average pocketbook, and a fine, tall white is today the scarcest thing in irises; Anna Farr is a tall, near-white and LaNeige is a dwarf nearwhite. Somewhat slow to get established and should have perfect drainage as well as plenty of lime in the soil. Roots

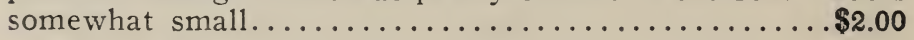

"Kashmir White is my tallest and best white, and is thrifty here (in Michigan). 
"Kashmir White, Fairy, Anna Farr, Princess Beatrice, and Aurea are my favorites.

"The grandest white for our locality (California); the past season it was the one variety enjoyed above all others.

LA NIEGE (Verdier, 1912)-A warm near-white of French origin; very pretty, and of medium size and height; horizontal falls and of good substance. 16-18 inches....75c

MRS. H. DARWIN (Foster, 1893)-S. white; F. white slightly marked with violet. A pretty little flower, early and a very profuse bloomer. $16-20$ inches..........20c

\section{White Standards and Darker Falls}

ANNE LESLIE (Sturtevant, 1918)-S. white with the finest flush of rose; F. rich carmine. Said to be richer than the similar French variety "Dahlia." Rich color effect, and a good grower. 24 inches...................\$1.00

RHEIN NIXE (G. \& K., 1910)-S. pure white; F. raspberry purple, edged white. Vigorous grower and dependable bloomer. Tall and moderately large flower. One of the indispensable varieties that should be in every garden.

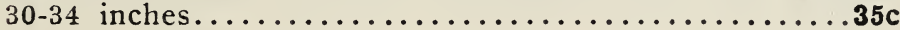

\section{Frilled and Dotted Effects}

CAMELOT (Bliss, 1918)-S. and F. creamy white edged with pale violet. About the tallest of the plicatas and a free bloomer. $42-48$ inches.........................\$1.00

MA MIE (Cayeux, about 1906)-S. white, frilled violet; F. white, penciled and margined violet. A lovely bloom. Called by some an improved Madam Chereau, but it is a much larger flower, $27-30$ inches..................35c

MADAM CHEREAU (Lemon, 1844)-S. and F. white with distinct and rather heavy frilling of blue-lavender. The old standard frilled variety and of good blooming habit. A pretty flower and medium-size bloom. Tall. 36 inches...20c

PARISIANA (Vilmorin, 1911)-S. white, heavily dotted lilac-purple; F. white, frilled at edge with lilac. A flower of unusual coloring and worthy of a place in any collection. Odd and yet pleasing. 27-30 inches 
VICTORINE (Lemon, 1840)-S. white, mottled blue; F. violet blue, mottled white. Medium-size flower and as dainty and pretty as an orchid. 27 inches..........25c

"In form and coloring this appeals to my serise of beauty strongly."

\section{$P$ in $k$}

EDOUARD MICHEL (Verdier, 1904)-Self-colored large flower of a deep wine-red color, the deepest of all the pinks. A grand iris and of imposing effect. Tall stems and blooms finely held. $30-36$ inches ........... \$1.00

"Is admired above all others in my garden.

"Is a superb Iris and after certain preliminary difficulties are surmounted, it blends inexplicably well in many striking combinations.

“Mr. W's. Ed. Michel was simply gorgeous-it stood above everything in his garden.

HER MAJESTY (Perry, 1903)-S. pretty shade of rosepink; F. darker with considerable veining, 20-22 inches..25c

MRS. ALLAN GRAY (Foster, 1909)-S. and F. a delicate, pale lavender or orchid-pink of a pleasing appearance. Dainty and pretty. 24 inches.................25c

PAULINE (Farr, 1913)-S. and F. unusually large rich pansy-violet, or say, deep pink; rich orange beard. Approaches Edouard Michel in its coloring, but does not equal it. One of the largest of the Farr hybrids, 36 inches....35c

WINDHAM (Farr, 1909)-S. soft lavender-pink; F. veined with darker shades. Not large but a very pretty, delicate pink. $24-28$ inches.......................

\section{Blue or Purple}

AMAS (wild; Asia Minor)-S. deep violet; F. sky-blue; one of the older varieties that is still liked. Fairly large bloom. Early bloomer. 24-27 inches.............20c

ARCHEVEQUE (Vilmorin, 1911)-S. purple-violet; F. rich, deep velvety purple. A stunning color and excelled by none in my gardens. Good grower and fine bloomer. One of the richest color effects. $24-28$ inches.........35c

"A wonderful block of Archeveque was the glory of the nursery." 
BALLERINE (Vilmorin, 1920)-S. light blue-violet, broad and rounded; F. a little deeper shade. Large flower on a tall stem; said to be among the very best of the French varieties. $3-4$ feet........................ \$2.00

BARONET (Sturtevant, 1920)-S. true chicory blue, with falls somewhat deeper in tone. Tall and medium-sized bloom. Color, tone and shading unusually good..... \$1.00

"It is one of the most effective garden Irises that I have ever seen. Close at hand it is not specially remarkable, but at a distance of thirty to fifty feet it is scarcely surpassed for garden effects. Its growth is strong and vigorous; the flower stands out finely and the blending and shading of color at the proper distance is as fine as any Iris."-F. B. Mead.

KOCHI (wild; Italy)-S. and F. rich claret-purple. Early and handsome. Its fault is that its blooms are likely to come and go very quickly; and it is not as tall as one would like:

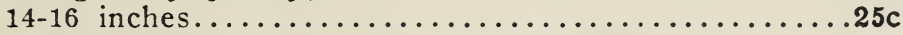

MONSIGNOR (Vilmorin, 1907) - S. rich violet; F. velvety purple-crimson, heavily veined. Fine coloring and good shape, though not a large flower. Late, 22-28 inches....35c

"A stately, massive and inspiring variety."

MRS. FRYER (Fryer, 1917)-S. white, shaded heliotrope; F. purple-crimson bordered, with a lighter shade, and veins of white. Said to be one of the best of the Fryer introductions, 32 inches..................50 c

OTHELLO (Lemon, about 1848) -S. rich blue; F. deep purple. One of the best of the older varieties. Rather small bloom, but a first-rate garden iris. Included by one grower in his list of the best purples. 25-30 inches.....20 c

PARC NUILLY (Verdier, 1910)-Both standards and falls are a rich purple self, approaching plum in color. Medium to large blooms, and fine in masses, 21-24 inches..30c

PERFECTION (Barr, about 1880)-S. light blue; F. dark violet-black. Handsome flower, but not quite as large as I would like to see it, considering its bold contrasts. Has more blossoms on the stalk than almost any other variety; still compares favorably with many of the novelties. A1ways attracts attention. $28-32$ inches............25c

SWATARA (Farr, 1918)-S. lobelia-blue with a warm yellowish glow; F. bright violet and a conspicuous beard. Cannot be said to be a large flower, though some catalogs tell you it is, but it is a very pretty bloom with a warm, rich effect. I regard it as one of the prettiest of the Farr hybrids, 36 inches.................... 
TAMERLANE (Vilmorin, 1904)-Deep violet-purple falls with paler standards. Easy, rapid grower and a large, handsome flower. One grower has said that this should have been called "Iris King." Very effective in masses. 28-34

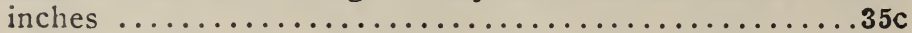

TROJANA (wild; Asia Minor) -S. pale blue; F. rich violet-purple. Large flower. Not a very profuse bloomer, however, and even the largest single rhizome may fail to flower the first year. Late bloomer and tall stalk: 32-36 inches ............................... and $30 \mathrm{c}$

One grower calls this a giant flower with rich falls; another says that it is of coarse texture and rather dull falls; the latter is nearer correct.

\section{Lilac and Violet or Pink-Violet}

ALBERT VICTOR (Barr, 1885)-S. soft blue; F. delicate, lovely lavender. Fine large blooms. Similar in coloring to P. Dalmatica, but taller and more erect. Good grower and bloomer. $36-42$ inches..............25c

BASHI-BAZOUK (Sturtevant, 1919)-S. light lavenderviolet; $F$. deepening to mauve. A flower of large size with long drooping falls, and of an unusual effect. A very satisfactory bloomer and grower. $30-36$ inches.........\$1.00

CATERINA (Foster, 1909)-Lavender-blue and lilac; almost the same coloring as P. Dalmatica except with a little pink showing. A beautiful flower and a graceful stem. Taller and larger than P. Dalmatica. Said to be a poor grower in very cold localities, but with me it is one of my best growers and with not a single fault to find in it. 40-45 inches. Price (according to size).....30 c and $40 \mathrm{c}$

"One of the most superb Irises that I have and this means something for I have over two hundred varieties.

"As Mr. W. grows it, it easily maintains a deserved position among the dozen best Irises I know of.

"Its fine color and smooth texture mark it as an aristocrat of the garden.

CRUSADER (Foster, 1913)-F. deep violet-blue with paler standards. The introducer claims this to be the finest of all blue irises. Splendid form; reported to be a slow grower by some. Mr. Wister (President of the A. I. S.) says the more he sees of this variety the better he likes it; he rates it 95 at least..................... $\$ 1.50$ 
LADY FOSTER (Foster, 1913)-S. pale blue; F. light bluish violet. Flowers unusually large, smooth and stout textured. Splendid, bold bloom. Rather slow grower with me. Praised very highly by some. $36-42$ inches...... \$1.25

LEWIS TROWBRIDGE (Farr, 1913)-S. bright violet; F. blue-violet, shaded rose. Vigorous grower and fine bloom. One of the largest of the Farr hybrids. Somewhat like P. Dalmatica in color, but with more rose in it, 30-36 inches, 35c

LEONIDAS (Europe, 1901) - S. clear mauve; F. rosy mauve. Large and of good form; tall. 30-32 inches....20c

LOHENGRIN (G. \& K., 1910)-Rich silvery lilac shaded deeper on the falls, of the tone of a Cattleya orchid. Fine, widely expanded flower. Close to being an extra fine bloom, says one grower. 30 inches.......................

Undoubtedly the most desirable of all the pallidas, says another grower, which is rather strong language, but the variety has many admirers without a doubt.

LORD OF JUNE (Yeld, 1916)-S. lavender-blue; F. rich violet-blue. An exceedingly handsome iris of fine proportions. Said by some to be one of the finest rises in the world. Finely suited as a cut flower for the house; out doors the petals are so large that they "flop" a little in warm sunshine or high winds. Its color, form and size are elegant, however, $30-36$ inches................. $\$ 1.00$

MAGNIFICA (Vilmorin, 1920)-S. light violet-blue; F. deep reddish-violet. Exceedingly large and long blooms on a tall stem. Personally, I do not think it one of the finest irises, but some do. Its color is good and its size immense, $3-4$ feet................................. 2.00

MANDELAY (Sturtevant, 1918)-A pale violet selfcolored variety not unlike Caterina, but a better grower in some localities. Fresh water-lily fragrant blooms. Large flower and tall stalk. $36-38$ inches............. 75c

MYTH (Sturtevant, 1918)-“"A very large pallid lavenderviolet flower, the segments unusually broad. S. open; F. widely flaring; most sumptuous in garden effect."-Introducer's description. 24 inches................\$1.25

NUEE D' ORAGE, OR STORM CLOUD (Verdier, $1905)$-S. slaty gray or heliotrope; F. bronze and purple. A soft pastel effect. Very large blooms and vigorous

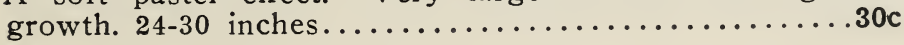


ORIFLAMME (Vilmorin, 1914)-S. light-blue; F. rich violet-purple. Somewhat early and enormous, handsome blooms; one of the largest of irises, 22-26 inches.......50c

PALLIDA DALMATICA OR PRINCESS BEATRICE (origin unknown)-S. light silvery lavender; F. clear and slightly deeper lavender. Large, fine blooms of perfect shape and admired by everyone. One of the older varieties not yet surpassed by any of the newer ones. I have the true variety, 30-34 inches. Prices, 30c, 40c, and 50c, according to size.

"The true Princess Beatrice is easily the most nearly perfect of any Iris that I know of."

QUEEN ALEXANDRIA (Barr, about 1910)-S. fawn, shot with lilac; F. lilac reticulated bronze at base. Smooth, cool texture and a very attractive bloom. Sturdy growth and good-sized flower, $20-22$ inches................

SINDJKHA (Sturtevant, 1918)-Deep dull lavender, shading to dark buff and violet; subdued tints; form, size and habit exceptional. A rich bloom. See below what Mr. Bliss, the famous English hybridizer says of it, 36-42

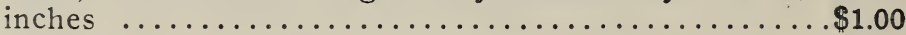

"The large flowers of very fine form and exceptional substance appear to me to be akin to the type to which Dominion and L. A. Williamson belong, tho the coloring is not so strong and bright. It has also the same sturdy stems and vigorous growth as these, and is freeflowering."

Another authority says "An established clump of this variety is irresistible.",

\section{Blended and Bronze Shades}

ALCAZAR (Vilmorin, 1910)-S. light bluish-violet; F. deep purple with bronze-veined throat. Somewhat somber, but a rich, large, striking bloom. Thought by some to be one of the richest effects in my garden. Late. 30 inches. $40 \mathrm{c}$

"Unsurpassed as a garden clump.

"Among the more sombre blends it was as magnificent, or more so, than it had ever been.

"With its tall and widely branching habit, makes probably the finest specimen clump of any Iris. (A. J. Bliss.)

"Easily the most popular variety among the darker blends.

AFTERGLOW (Sturtevant, 1917) - Soft grayish lavender shading to a rich yellow through the center. Of loose 
pallida form and strong growth. Generally admired by all who see it, $32-36$ inches................ $75 \mathrm{c}$

"Several of the Sturtevant seedlings in this garden ranked among the aristocrats: Sindjkha, Sherbert, and the exquisitely-toned Afterglow."

AMBASSADEUR (Vilmorin, 1920)-Smoky bronze with dark velvety maroon falls. Considered the finest of Vilmorin's seedlings and an extremely rich bloom. Large size. $32-36$ inches........................\$2.00

"If it were necessary to name the best Iris in the world today, I would decide upon this variety.

"I would not change Ambassadeur in any respect.

"Most impressive and a splendid grower.

"In a class by itself and most imposing in substance, form and color.

ARNOLS (Barr, 189 )-S. bronze with rosy tints; F. rich soft velvet. Handsome medium-sized blooms. Among the bronze types this is one of the most attractive. Almost as fine as Prosper Laugier and a faster grower, 24-26

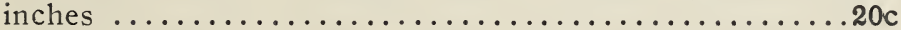

"An old variety and was very splendid this season-finer far than many a heralded new variety."

ELDORADO (Vilmorin, 1910)-S. fiery opalescent; F. old gold and burnt purple. A combination amazing and unusual in effect. Flower often comes small and with a weak stem. but the last season (one with more rain than usual). the stem was good and the flower large, tho it never approches the ideal shape, 25-28 inches............35

"Eldorado was in beautiful form, and, massed with the exquisitely blending Quaker Lady, made a stunning corner in the garden. Both of these varieties are favorites with me.

"Eldorado was again the one to maintain the longest season, Monsignor being next.

ISOLINE (Vilmorin, 1904)-S. pinkish lilac; F. old rose with a tinge of copper. A beautiful piece of coloring and hard to describe. There isn't a thing in the garden that excels it in sheer beauty of coloring. Large flowers, but a shy bloomer at times. Tall, 36 inches............35c

"An indescribably beautiful thing. The stalk is magnificent and the buds just before unfolding are awe-inspiring.

"Among the finest pinkish Irises in existence.

"It resembles nothing but itself. There mingle in its tall uprights and broad falls all the pale shades of auburn, sepia and rose.

IRIS KING (G. \& K., 1907)-S. rich yellow shaded fawn; F. rich maroon with yellow beard. Fine coloring and a handsome iris, but not large, even though some growers describe it as such. One of the indispensables that should be in every garden. About 26 inches.............. 
JACQUESIANA (Lemon, 1840) - S. bright copper-crimson; F. rich maroon. Among the best of the older varieties and still holds its own with Iris lovers. 30-36 inches....30c

"Is of striking beauty and stands well at the front of the old varieties.

"We prefer it to P. Laugier, but most visitors prefer the latter.

L. A. WILLIAMSON (Williamson, 1918)-S. soft campanula-violet; F. velvety royal-purple; brilliant golden beard. Massive in flower and growth. Said by some to be one of the finest in the world, $36-42$ inches..\$1.00 and $\$ 1.25$ according to size.

"This is the best Iris seedling that has yet been raised in America. The flowers are very large, of the finest form and of great substance, surpassed only by Dominion. The coloring is rich, velvety and bright tho the crimson-purplish tone in the red-brown falls make it a little harsh. It is exceptionally free-flowering. Few, if any, Irises can claim such all-round excellence." A. J. Bliss.

"These three Irises (I. A. Williamson, Alcazar, and Ballerine) were the monarchs of my garden the past season.

PROSPER LAUGIER (Verdier, 1914)-S. smoky-brown; F. rich wine-red. Handsome and one of the best of the bronze varieties. Not a large flower, however. 30 inches, $35 \mathrm{c}$

PROSPERO (Yeld, 1920)-S. pale lavender; F. velvety red-purple. Large blooms of good substance and a reliable grower. Tall, stiff, well-branched stems. Unusually fine iris. $36-40$ inches...................\$2.00

QUAKER LADY (Farr, 1909)-S. smoky lavender with yellow shadings; $F$. ageratum-blue and old gold. Odd and attractive. Not large but considered to be one of Farr's most attractive and popular seedlings, $30-33$ inches........35c

SHERBERT (Sturtevant, 1918)-S. drab and cinnamon and purple; F. dahlia-purple shaded lighted at edges. An odd blending of colors. Flexuous and tortuous stems which are a pronounced defect in this variety. Good grower and large blooms. $32-36$ inches...............50c

\section{Yellow}

AUREA (Jacques, 1834)-S. and F. rich chrome-yellow. Perhaps the finest yellow at a low price. Good sized, but not large blooms of fine form. 24 inches.........25c

\footnotetext{
"The best all-round yellow garden Iris; it seems to tone so well with many of the other varieties that it is very useful in quantities."
} 
DAWN (Yeld, 1912) - Very pretty sulphur-yellow bloom, amber-veined at the throat. One of the newer English introductions. Attractive bloom, tho small. 28-30 inches. 35c

DARIUS (Parker, 1873)-S. clear rich yellow; F. lilacblue rimmed with white. Quite pretty and dainty, but

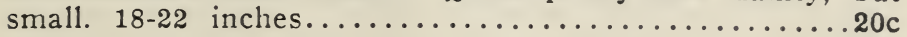

"This old variety has not yet been equalled in its class by any of the newer introductions. . . . Its standards are a clear, beautiful yellow and the hazy lilac color of its falls seems to detach it from the earth and the rest of the plant, and give it that evanescent quality for which the Iris surpasses all other flowers."

FLAVESCENS (Europe, before 1830)-Both standards and falls are soft yellow; wonderfully delicate, and of good size and growth. One of the older yellows that still retains its hold on the iris public, $30-32$ inches..........20 c

HELGE (G. \& K., 1908)-Both S. and F. lemon-yellow One of the early or "intermediate" types, and of good size

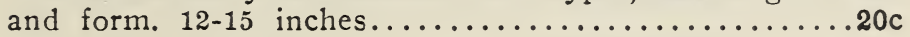

LORELEY (G. \& K., about 1909)-S. light yellow; F. ultramarine bordered with cream. Good grower and striking contrasts, 30 inches.....................

"Loreley is a gem and the fastest multiplier on my place."

MINNEHAHA (Farr, 1913)-S. creamy white, shaded yellow; F. same, but heavily marked with maroon. Blooms of good size. One of Farr's hybrids that is more esteemed in Europe than most of his other introductions. Rather massive and distinct, 24 inches................

MRS. NEUBRONNER (Ware, about 1898)-S. and F. very deep, rich yellow. Its color is good, but its height and size and shape are against it. I am listing it for there is no other yellow so deep and intense. 14-16 inches.......20 c

PRINCESS VICTORIA LOUISE (G. \& K., 1910)S. soft clear yellow; F. rich plum, bordered cream. Gay and gaudy and good for lighting up dark spots in the garden. Of good size and growth and very floriferous. 24-30

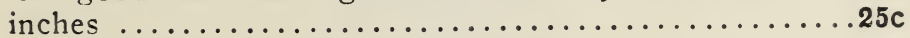

SHEKINAH (Sturtevant, 1918)-A pale lemon-yellow pallida. not large in size, but on a moderately tall stalk, and generally admired. $30-34$ inhes............... \$2.00 


\section{TWO OF THE SIMPSON SEEDLINGS.}

ARLINGTON (1924)-S. Clear rosy lavender; $\mathrm{F}$. bright velvety reddish violet, almost crimson in effect. Very large bloom and a thrifty grower. Commented on and admired by all who have seen it. Said by many to be about the prettiest variety in my garden. $32-36$ inches.............. \$3.00

"Arlington is in all its glory; one of the rhizomes you sent has a wonderful bloom. I think it is as fine an Iris as I have ever had.-Tennessee.

"A new seedling from Mr. H. P. Simpson caused considerable comment; its large size and clear coloring were doubly attractive.-Takoma Park, D. C.

"The outstanding bloom in my garden.-Tennessee.

"Your Arlington is better than L .A. W. in that it is taller, of better color and without the somberness of that variety. It is a thoroughly good Iris.-Alabama.

"Arlington bloomed fine for me and was better than Prospero (a choice English variety).-Michigan.

"I consider that one stalk of Arlington which I included in an exhibit of 12 varieties at the Mass. Hort. Exhibition, was the means of my obtaining first prize.-Miss Sturtevant, Massachusetts.

CALEBEE (1925)-An Indian name, pronounced 'Ca-le-by'. An unustially rich plicata; S. lavender and white, with reddish-brown markings, particularly on the falls, giving the entire flower an attractive bronzy effect. Medium size bloom and somewhat narrow petals. A very pretty effect that attracted many who have seen it blooming. Good grower. $22-24$ inches...............\$1.25

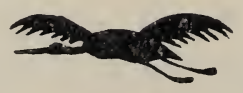




\section{A FINE COLLECTION AT A LOW PRICE.}

For those beginning the fascinating culture of Irises, a collection (my selection) of ten varieties, all named, will be sent for $\$ 2.50$, made up from the following choice kinds: Pauline, Lewis Trowbridge, Albert Victor, MaMie, Storm Cloud, Windham, Tamerlane, Her Majesty, Innocenza, Amas, Caterina, Princess Victoria Louise, Fairy, Rhein Nixe, Parisiana, Lohengrin and Swatara. State your choice if you have any. This collection can be highly recommended to any one beginning their venture into the glories of Irisland.

\section{A MORE EXPENSIVE COLLECTION OF SOME OF THE SCARCER KINDS FOR \$5.00.}

Fenella

Archeveque

Myth

Alcazar

Quaker Lady

Minnehaha
Ed. Michel

Monsignor

Oriflamme

Isoline

Dawn

Anne Leslie

The above if bought separately would cost you $\$ 7.00$.

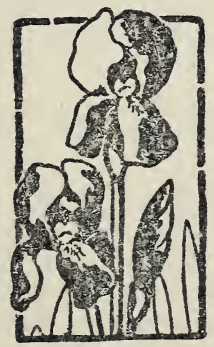




\section{WHAT THEY THINK OF THE STOCK I SEND OUT.}

The extracts given here are from actual letters on file that have been received from appreciative customers :

II I must write and tell you how well the plants you sent me last June have done-especially the ones considered by so many the hardest to grow: Kashmir White, Ed. Michell and Caterina-have all grown wonderfully well. Without exception they have surely shown how splendid must be the quality of the stock sent out.-T. P. H., Pennsylvania.

II I bought Princess Beatrice from seven different growers and only yours pulled through the winter-the worst winter we ever had.-K. P. W., Tennessee.

I The roots ordered are fine and I have every confidence that they will do well and will give me some such glorious blooms as you had at the Iris Show.-J. P. K., Virginia.

I. Your Iris roots for the school arrived this morning, and in the usual H. P. Simpson fashion-everything fine and ship-shape.-I. A. T., District of Columbia.

II I wish to thank you for the very generous manner in which you filled my order-fine roots and an extraordinary conception of "single" roots.-E. T. H., Virginia.

If The Iris roots came today and are very fine.-F. E. D., Massachusetts.

II I duly received the Irises ordered and was, as usual, delighted with the stock sent me. I have purchased from a great many growers and think it is fair to you to state that at no time have I secured better plants from any of them. I am interested in your seedlings and will accept a shipment of any such that you think would be worth my while for which you may bill me, and I will forward my check.R. G., Pennsylvania. 


\section{TERMS OF SALE.}

Cash with order by either check or money order.

Orders of less than one dollar are respectfully declined.

Orders by the dozen or more: While I am not a wholesaler and do not grow in large quantities, as a rule and with all except the scarce kinds, I can supply 12 roots of any one variety for the price of ten, but not 12 roots of different varieties, please keep in mind. I may be slightly higher on a very few kinds than some growers, but this can be due to the larger sizes of my roots-in fact I know it is in some cases, judging from my own purchases and from what others have told me. Anyway, please note how much lower most of the prices are than those quoted by the average reliable grower!

Shipping Time: My preference, and that of the great majority, is after the plants have bloomed, which with me is after June 10th. From this date until September 1st, is undoubtedly the best transplanting time; and to prove this, I do all my own transplanting then! However, I can accommodate those who wish the roots delivered in the spring if they will so direct me.

Size of Roots: They are mostly of the so-called "blooming size" (the rarer varieties will run somewhat smaller, however), though it has been found that about one-fourth of these will not bloom the first season after transplanting, due to some cause which no one can control. Different varieties give us different-sized rhizomes; for instance, Othello, Windham, Iris King, etc., naturally produce small or rather small ones, while Lewis Trowbridge, Pauline, Caterina and others produce the larger ones. 
At the Iris Society's national show, held in Washington, May, 1924, not only was the Society's bronze medal awarded my general display of seedlings, but Awards of Merit were bestowed on three special ones. Two of these will be offered for sale in 1926; one, No. 29a, is a plicata on the order of Madam Chereau, but much more beautiful and larger; the other, No $49 \mathrm{a}$, is a very deeply colored rich bloom, somewhat related to Arlington; the third, No. 3a, is a magnificently large bloom of a very deep reddish purple, but its blooming habit will have to be further tested before I can recommend it for general planting. This last mentioned variety was easily the largest bloom in the entire show, though the other two were not far behind it in size!

Satisfaction is absolutely guaranteed to all reasonable purchasers. On receipt of an order, if unsatisfactory to you, return the roots promptly in gond condition and the purchase price will be as promptly remitted. I am not in the Iris business simply to make money out of it, and any other policy than this would utterly fail to be satisfactory to me. Be reasonable, though, please, and if you have never bought Iris before, do not expect the earth for the prices asked. I do not send out "nubbins," as some growers do, but still keep in mind what was said above, that some varieties naturally grow small rhizomes, while other grow large ones.

A Word of Caution: Go slow about ordering any of the very expensive American or foreign varieties, unless you have seen them blooming and hence know them;-I mean those costing five, ten and fifteen dollars or more. Many of them are absolutely not needed in anyone's garden, and many of them are not worth over one or two dollars eachmuch less five or ten! 


\section{SIIPPING AT BLOOMING TIME}

On the preceding pages, through inadrertence, it was neglected to state that roots cannot be shipped during blooming time, which, with me, is about from May 1st to June 10th. As mentioned before, the best transplanting time is during June, July and dugust; the plants are dormant or somewhat so then, and, besides, better ones, as a rule, can be then sent. Reservations can be made ahead of time for delirery during these months if accompanied by 25 per cent of the amount your orcler calls for; the balance to be paid upon receipt of the plants.

Howerer. if you strongly desire spring delivery, and the ferer for planting then cannot be resisted, state so, and rou will be accommodated with the best roots possible to send you. 


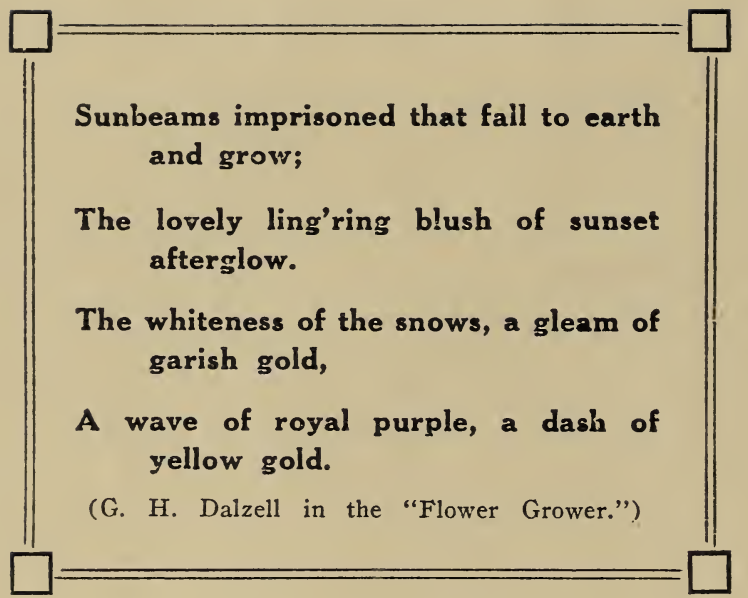

